\title{
DIVERSIFIKASI OLAHAN SUSU KAMBING MENJADI KRUPUK SUSU DI KELOMPOK WANITA TERNAK KECAMATAN SURUH KABUPATEN TRENGGALEK
}

\author{
Ahsin Daroini ${ }^{1)}$, Efi Rokana ${ }^{1)}$, Riska Nurtantyo Sarbini ${ }^{2)}$ \\ 1)Prodi Peternakan Fakultas Pertanian Universitas Islam Kadiri \\ 2) Prodi Teknik Elektro Fakultas Teknik Universitas Islam Kadiri
}

Alamat e-mail : daroiniahsin17@gmail.com

\section{RINGKASAN}

\begin{abstract}
Penganekaragam produk susu menjadi dodol susu, permen susu, susu bubuk, yoghurt, dan es krim dilakukan dengan menggunakan bahan susu murni yang berkualitas, sedangkan pembuatan kerupuk susu justru memanfaatkan susu yang tidak memenuhi standar kualitas atau diistilahkan dengan susu pecah. Pengolahan susu pecah menjadi kerupuk susu merupakan solusi pemanfaatan bahan berkualitas rendah menjadi olahan berkualitas tinggi dan lebih berdaya saing. Pelaksanaan Program Kemitraan Masyarakat (PKM) ini dilakukan dengan menggunakan metode partisipatif, penyuluhan, pendampingan, dan pelatihan di lokasi kedua mitra di Kecamatan Suruh Kabupaten Trenggalek. Pemecahan masalah pada kedua mitra dari aspek produksi dan aspek manajemen dilakukan secara bertahap serta melibatkan peran aktif mitra dalam pelaksanaa program secara berkesinambungan. Hasil PKM menunjukkan bahwa permintaan pasar sangat terbuka luas dan bahan baku susu kambing di Kecamatan Suruh cukup tersedia. Sosialisasi, pelatihan dan pendampingan tentang cara pengolahan susu kambing menjadi kerupuk susu dalam rangka diversifikasi produk, pengemasan produk, teknik pemasaran secara on line, pencatatan keuangan usaha, jaminan keamanan produk berupa nomor PIRT dan bantuan fasilitas produksi berupa mesin pengering dan pengiris/pemotong kerupuk sudah dilaksanakan di kedua mitra dan respon mitra sangat bagus untuk mendukung keberlanjutan program PKM ini dalam kegiatan usaha selanjutnya. KesimpulanPKMadalahprodukkrupuksususudahdiproduksiolehmitradenganmelakukanpengemasan yang bagus dan memiliki PIRTserta jangkaun pemasaran yang lebih luas melalui media internet. Saran yang diberikan adalah sebaiknya instansi terkait senantiasa memberikan evaluasi dan pembinaan secara berkala mengenai keberlanjutan usaha pengolahan susu kambing khususnya di Kecamatan Suruh.
\end{abstract}

Kata kunci : kerupuk susu, susu pecah, Kelompok Wanita Ternak, diversifikasi produk, pemasaran secara on-line

\section{PENDAHULUAN}

\section{Analisis Situasi}

Kerupuk susu merupakan jenis makanan ringan, sehat dan bergizi yang kemungkinan disukai oleh anak-anak dan orang dewasa. Melalui proses pengolahan pangan yang tepat kerupuk susu dapat bertahan hingga berbulanbulan tanpa bahan pengawet. Pembuatan kerupuk susu memerlukan penambahan bahan pengembang, misalnya baking powder. Pemberian baking powder bertujuan untuk memberi daya kembang pada kerupuk yang akan dibuat. Penelitian yang dilakukan Ratna (2016) tentang pengaruh dosis baking powder terhadap sifat organoleptik kerupuk susu menunjukkan bahwa kerupuk susu yang diberi perlakuan dosis baking powder berbeda $(0,1 \%, 0,3 \%, 0,5 \%, 0,8 \%$, $1 \%$ ) berpengaruh nyata terhadap kerenyahan. Hasil uji organoleptik menyatakan bahwa ratarata skor tertinggi dari kerenyahan terdapat pada perlakuan pemberian dosis baking powder $1,0 \%$. Jadi semakin tinggi taraf pemberian dosis baking powder terhadap pembuatan kerupuk susu akan memberikan tingkat kerenyahan yang lebih, 
tetapi tidak berpengaruh terhadap warna, rasa, dan aroma.

Penganekaragam produk susu menjadi dodol susu, permen susu, susu bubuk, yoghurt, dan es krim dilakukan dengan menggunakan bahan susu murni yang berkualitas, sedangkan pembuatan kerupuk susu justru memanfaatkan susu yang tidak memenuhi standar kualitas atau diistilahkan dengan susu pecah. Pengolahan susu pecah menjadi kerupuk susu merupakan solusi pemanfaatan bahan berkualitas rendah menjadi olahan berkualitas tinggi dan lebih berdaya saing. Pengolahan susu pecah menjadi kerupuk susu tersebut dapat dilakukan di sentra-sentra penghasil susu, misalnya Kecamatan Suruh Kabupaten Trenggalek yang merupakan sentra susu kambing Peranakan Etawa.

Kelompok Ternak Kambing di Kecamatan Suruh Kabupaten Trenggalek mempunyai usaha utama yaitu budidaya kambing Peranakan Etawa (PE). Anggota kelompok pria melakukan kegiatan budidaya kambing secara intensif, sedangkan anggota kelompok wanita melakukan kegiatan proses pengolahan susu kambing yang dihasilkan. Adanya kerjasama yang sinergis tersebut diharapkan kegiatan budidaya kambing PE dapat bertahan dan dikembangkan secara berkesinambungan.

Sebagaimana diketahui wilayah Kecamatan Suruh Kabupaten Trenggalek berada di kawasan perbukitan kurang lebih 700 meter di atas permukaan laut, yang mana sangat berpotensi untuk budidaya ternak kambing, oleh karena udaranya yang sejuk, banyak lahan pakan baik milik perorangan maupun lahan perhutani yang dikelola oleh masyarakat. Selain itu juga didukung oleh banyaknya lahan rumput lapang, limbah pertanian, sehingga tidak kuatir kalau terjadi kekurangan pakan. Total populasi kambing PE di Kecamatan Suruh sebanyak 22.000 ekor induk produkstif, yang mana sebagian besar terdapat di Desa Wonokerto dan Desa Puru. Mata pencaharian utama masyarakat di Kecamatan Suruh adalah sebagai peternak kambing PE.

Adanya daya dukung yang bagus tersebut tidaklah mengherankan kalau jumlah produksi susu kambing yang dihasilkan kelompok ternak kambing "Kerta Usaha" di Kecamatan Suruh cukup tinggi hingga mencapai 2000 liter setahun pada tahun 2014. Oleh karena itu agar hasil produksi susu kambing PE yang tinggi tersebut dapat bermanfaat secara maksimal, disamping dijual dalam bentuk susu segar kiranya perlu ada upaya pengolahan untuk memperpanjang daya simpan, memanfaatkan susu yang tidak memenuhi standar/ susu pecah dan deversifikasi produk. Usaha pengolahan susu tersebut dilaksanakan dan dikembangkan oleh kelompok wanita ternak di Kecamatan Suruh, yaitu dengan mengolah bermacam-macam produk olahan susu. Selama ini apabila terjadi kasus penolakan susu maka upaya yang dilakukan adalah susu diberikan untuk cempe atau dibuang begitu saja, padahal terdapat solusi yang bagus yaitu mengolahnya menjadi kerupuk susu.

\begin{tabular}{|l|l|l|}
\hline Data & Mitra I & Mitra II \\
\hline Nama Kelompok & Kerta Usaha & Banar Lestari \\
\hline Nama Ketua & Rini Sejati & Sulistriani \\
\hline Lokasi & $\begin{array}{l}\text { Desa Wonokerto } \\
\text { Kecamatan Suruh } \\
\text { Kabupaten Trenggalek }\end{array}$ & $\begin{array}{l}\text { Desa Puru Kecamatan Suruh Kabupaten } \\
\text { Trenggalek }\end{array}$ \\
\hline Usaha yang dikelola & $\begin{array}{l}\text { Pengolahan Susu Kambing } \\
\text { menjadi: Susu bubuk; } \\
\text { Krupuk Susu; Stick Susu; } \\
\text { Permen Susu }\end{array}$ & $\begin{array}{l}\text { Pengolahan Susu Kambing menjadi: } \\
\text { Stick susu; Susu bubuk; Permen susu; } \\
\text { Pastel susu; Krupuk susu }\end{array}$ \\
\hline Skala usaha & $\begin{array}{l} \pm \text { liter susu kambing/2 } \\
\text { minggu }\end{array}$ & \pm 1 liter susu kambing/ 1 minggu \\
\hline
\end{tabular}




\begin{tabular}{|c|c|c|}
\hline Lama usaha & Mulai 2008 & 5 bulan \\
\hline Metode Pengolahan Susu & Tradisional & Tradisional \\
\hline $\begin{array}{l}\text { Merk Dagang Kerupuk } \\
\text { Susu }\end{array}$ & $\begin{array}{l}\text { Krupuk Susu " Kerta } \\
\text { Usaha" }\end{array}$ & Krupuk Susu "Banar Lestari” \\
\hline Jaminan Produk & Belum ada PIRT & Belum ada PIRT \\
\hline $\begin{array}{l}\text { Kemasan Produk Kerupuk } \\
\text { Susu }\end{array}$ & Plastik + label & Plastik + label \\
\hline $\begin{array}{l}\text { Lama simpan Kerupuk } \\
\text { Susu }\end{array}$ & \pm 3 minggu & \pm 3 minggu \\
\hline Pemasaran & Pasar Lokal & Pasar Lokal \\
\hline Aset yang dimiliki & $\begin{array}{l}\text { Sealer : } 1 \text { buah; Wajan : } 1 \\
\text { buah; Penggiling stick : } 1 \\
\text { buah; Kompor }+ \text { tabung } \\
\text { gas : } 1 \text { buah; Ember : } 2 \\
\text { buah; Timbangan tepung: } \\
1 \text { buah }\end{array}$ & $\begin{array}{l}\text { Wajan : } 1 \text { buah; Sealer : } 1 \text { buah; Ember } \\
: 2 \text { buah; Kompor }+ \text { tabung gas : } 1 \\
\text { buah; Penggilingan stick : } 1 \text { buah; } \\
\text { Timbangan tepung : } 1 \text { buah }\end{array}$ \\
\hline
\end{tabular}

Secara umum pengolahan kerupuk susu yang dijalankan oleh kedua mitra masih secara tradisional, pengemasan dan pemasarannya juga masih sangat sederhana, selain itu juga belum melakukan pencatatan keuangan usaha secara tertib. Seperti diketahui bahwa pengolahan kerupuk susu yang tepat dapat menjamin tingkat kesukaan konsumen, baik dari segi kualitas organoleptik (rasa, warna, bau dan kerenyahan) maupun kualitas kimiawinya. Perbandingan tepung tapioka dengan susu yang tepat serta penggunaan bahan tambahan makanan yang aman dan tidak membahayakan konsumen kiranya perlu diperhatikan saat pengolahan kerupuk susu di kedua Mitra. Hal tersebut berperan dalam menghasilkan rasa, warna, bau dan kerenyahan yang bagus untuk produk kerupuk susu.

Upaya yang dilakukan mitra untuk mengurangi kadar air kerupuk susu adalah dengan menjemur di bawah terik sinar matahari selama \pm 3 hari. Apabila cuaca mendung maka proses produksi kerupuk jadi terhenti karena proses pengeringan kerupuk memerlukan waktu yang lama sehingga menyebabkan kerupuk menjadi berjamur, sehingga tidak dapat melayani permintaan pesanan ataupun menjual di warungwarung untuk memenuhi keperluan warga sekitar . Proses pengeringan yang sempurna, pemotongan yang tipis dan pemberian bahan tambahan yang tepat yaitu baking powder dapat menghasilkan kerupuk susu yang renyah setelah digoreng.
Melalui Program Kemitraan Masyarakat (PKM) ini diharapkan dengan pemberian bantuan berupa mesin pengering dan pemotong/pengiris kerupuk kepada kedua mitra dapat membantu proses produksi sehingga dihasilkan kerupuk susu yang lebih tahan lama dan berkualitas secara organoleptik sehingga disukai konsumen.

\section{Program Kemitraan Masyarakat (PKM)} ini dilaksanakan untuk meningkatkan volume penjualan kerupuk susu kedua mitra dan memberikan motivasi kewirausahaan bagi kelompok wanita peternak kambing yang lain di Kecamatan Suruh Kabupaten Trenggalek sehingga dapat mendukung program pemberdayaan wanita dan meningkatkan pendapatan masyarakat.

\section{TARGET DAN LUARAN}

Target dalam program PKM ini adalah:

1. Meningkatnya pemahaman mitra tentang perlunya menerapkan teknologi pengolahan susu kambing menjadi kerupuk susu, sebagai upaya untuk penganekaragaman produk dan memanfaatkan susu kambing yang tidak memenuhi standar/susu pecah.

2. Meningkatnya ketrampilan mitra untuk mengolah susu kambing menjadi kerupuk susu yang berkualitas secara organoleptik serta cara mengoperasikan mesin khusus pengering dan pemotong kerupuk, sehingga 
kerupuk susu yang dihasilkan dapat lebih tahan lama dan berukuran seragam. Adanya deversifikasi produk yaitu dengan mengolah susu kambing menjadi kerupuk susu dapat memenuhi permintaan konsumen yang menginginkan tersedianya camilan ringan yang bergizi dengan masa simpan yang lebih lama.

3. Meningkatnya ketrampilan mitra dalam proses pemasaran produk melalui pemanfaatan kemajuan di bidang teknologi informasi yaitu pemasaran secara on line.

4. Meningkatnya ketrampilan mitra dalam proses pengemasan produk sehingga pemasarannya lebih praktis dan memiliki nilai estetika.

5. Meningkatnya pemahaman dan ketrampilan mitra tentang perlunya pencatatan keuangan. usaha.

6. Adanya jaminan keamanan produk yang dihasilkan mitra untuk dikonsumsi oleh karena didapatkannya nomor PIRT dari Dinas Kesehatan.

\section{Capaian Luaran}

\begin{tabular}{|l|l|c|}
\hline No & Jenis Luaran & Capaian \\
\hline 1 & $\begin{array}{l}\text { Publikasi ilmiah di jurnal/Prosiding } \\
\text { Kegiatan IbM dipublikasikan di Jurnal } \\
\text { Dedikasi Univ. Muhamdiyah Malang } \\
\text { ISSN 1693-3214; Januari 2019 }\end{array}$ & $100 \%$ \\
\hline 2 & $\begin{array}{l}\text { Pemakalah dalam temu ilmiah } \\
\text { Mengikuti Seminar Hasil Pengabdian } \\
\text { Masyarakat oleh LP3M Uniska; } \\
\text { Oktober 2018 }\end{array}$ & $100 \%$ \\
\hline 3 & $\begin{array}{l}\text { Hak Kekayaan intelektual (Paten, } \\
\text { Paten sederhana, Hak Cipta, Merek } \\
\text { Dagang, Rahasia Dagang, Desain } \\
\text { Produk Industri, Perlindungan Varietas } \\
\text { Tanaman, Perlindungan Topografi } \\
\text { Sirkuit Terpadu) }\end{array}$ & \\
\hline 4 & Teknologi Tepat Guna & $100 \%$ \\
\hline 5 & $\begin{array}{l}\text { Karya Seni/Rekayasa Sosial, Jasa, } \\
\text { Sistem, Produk /Barang }\end{array}$ & $100 \%$ \\
\hline 6 & $\begin{array}{l}\text { Buku Ajar (ISBN) } \\
\text { Kegiatan PKM disusun dalam sebuah } \\
\text { Buku Ajar ber ISBN Penerbit CV } \\
\text { Dimar Intermedia; Oktober 2018 }\end{array}$ & \\
\hline 7 & $\begin{array}{l}\text { Publikasi pada media massa (cetak/ } \\
\text { elektronik) }\end{array}$ & $100 \%$ \\
\hline
\end{tabular}

\section{METODE PELAKSANAAN}

\section{Permasalahan Mitra dari Aspek Produksi}

1. Selama ini kelompok wanita ternak kambing hanya memanfaatkan susu kambing yang memenuhi standar untuk dibuat produk olahan susu. Belum dikembangkan untuk memanfaatkan susu yang tidak sesuai standar/susu pecah untuk produk khususnya kerupuk susu.

2. Kerupuk susu yang diolah selama ini masih menggunakan cara yang tradisional sehingga kurang menjamin kualitas secara organoleptik dan fisiknya yaitu hasil irisan kerupuknya masih tebal dan belum seragam.

3. Kurangnya peralatan dan fasilitas produksi seperti alat untuk pengeringan dan pemotongan kerupuk sehingga kapasitas produksi dan masa simpannya belum maksimal.

4. Belum dilakukan pengemasan secara khusus pada produk kerupuk susu, sehingga pemasaran tidak dapat dilakukan secara lebih luas.

\section{Permasalahan Mitra dari Aspek Manajemen}

1. Terbatasnya pengetahuan dan ketrampilan di bidang pemasaran dengan memanfaatkan kemajuan teknologi informasi, sehingga target pasar kurang luas.

2. Jaminan keamanan produk belum dilakukan oleh mitra.

3. Belum adanya pencatatan keuangan yang tertib pada usaha yang dijalankan.

Solusi yang ditawarkan untuk menyelesaikan permasalahan

Dari identifikasi permasalahan mitra dari aspek produksi dan aspek manajemen dapat dilakukan solusi penyelesaian sebagai berikut:

1. Pembinaan dan pelatihan untuk memanfaatkan susu kambing baik yang sesuai standar maupun yang tidak sesuai standar untuk diversifikasi produk yaitu kerupuk susu sehingga mitra dapat menghasilkan produk kerupuk susu yang lebih baik kualitas organoleptik dan fisiknya.

2. Melengkapi fasilitas produksi yaitu dengan menambah alat berupa mesin khusus 
pengering untuk mengurangi kadar air dan pemotong kerupuk, dimana selama ini upaya untuk mengurangi kadar air kerupuk susu tersebut masih dilakukan dengan dijemur dibawah terik sinar matahari, yang sangat tergantung pada musim, sehingga kurang efisien dalam hal tenaga dan waktu. Diharapkan dengan mesin khusus pengering yang diberikan, proses pengeringan kerupuk susu menjadi lebih sempurna sehingga lebih tahan lama. Adanya alat khusus untuk mengiris/memotong kerupuk diharapkan kerupuk susu yang dihasilkan lebih tipis dan seragam bentuknya.

3. Membuat desain pengemasan produk yang menarik sehingga dapat diterima pasar dan dapat dipasarkan ke wilayah yang lebih luas.

4. Melakukan survey dan mencari area pemasaran yang baru dengan memanfaatkan kemajuan teknologi informasi, sehingga area pemasaran produk menjadi lebih luas.

5. Melakukan pencatatan keuangan usaha secara tertib.

6. Memfasilitasi dalam pengurusan nomor PIRT dari Dinas Kesehatan sehingga produk dapat dijamin keamanan dan kelayakannya untuk dikonsumsi.

Program Kemitraan Masyarakat (PKM) ini dilakukan dengan menggunakan metode partisipatif, penyuluhan, pendampingan, dan pelatihan di lokasi kelompok wanita ternak kambing Kecamatan Suruh Kabupaten Trenggalek.

\section{HASIL}

\section{Survey Lokasi PKM}

Survey lokasi perlu dilakukan untuk mengetahui perkembangan usaha dan menginventarisir permasalahan yang dihadapi kedua mitra. Berdasarkan hasil survey diperoleh informasi bahwa usaha mitra I dan mitra II telah mengalami perkembangan yaitu dengan bertambahnya volume penjualan camilan stick susu dan susu bubuk, meskipun peningkatannya belum terlalu besar. Hal tersebut salah satunya disebabkan masih terkendala oleh keterbatasan alat produksi.
Permasalahan yang dijumpai pada kedua mitra dapat ditinjau dari aspek produksi dan manajemen. Berdasarkan hasil survey diperoleh informasi bahwa untuk mitra I dan mitra II masih kesulitan dalam memperluas pemasaran produk olahan susu kambing yang dihasilkan kelompok, sehingga Tim PKM intensif dalam membantu memperluas pemasaran dengan bantuan media internet. Sementara itu produk krupuk susu juga belum diproduksi secara kontinyu dan hasilnya juga masih belum bagus berdasarkan uji organoleptik. Melalui program PKM maka dilakukan penyusunan schedull untuk pelatihan pembuatan krupuk susu dan cara membuka pasar, memperbaiki kemasan yaitu dengan menggunakan plastik mika dan kertas. Baik mitra I dan mitra II belum memiliki nomor PIRT untuk produk krupuk susunya.

Adapun permasalahan yang lain selanjutnya dibantu TIM Pengmas Uniska untuk dicarikan solusinya sesuai dengan rencana program PKM yang telah disetujui oleh Kemristek Dikti dengan menggunakan dana tahun anggaran 2018.

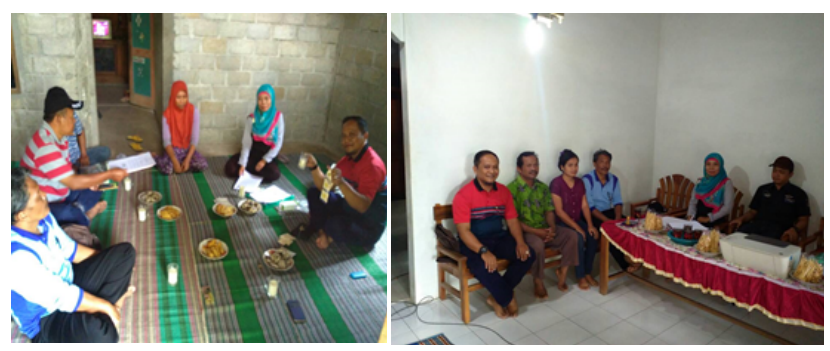

Gambar 1. Survey di lokasi mitra I dan mitra II

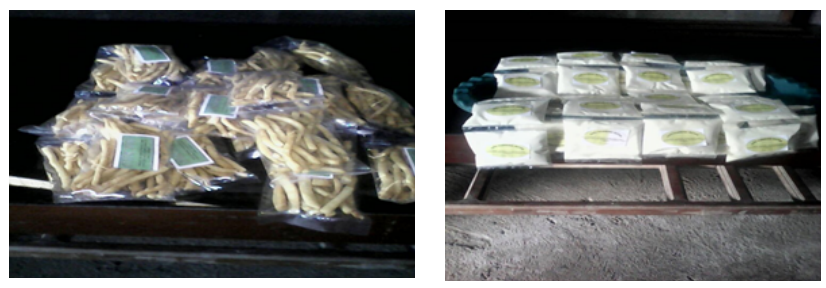

Gambar 2. Produk Stick Susu dan Susu Bubuk mitra
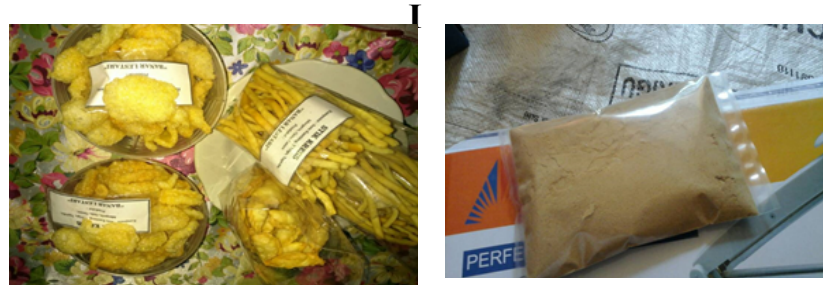

Gambar 3. Produk Krupuk Susu, Stick Susu, dan Susu Bubuk mitra II 

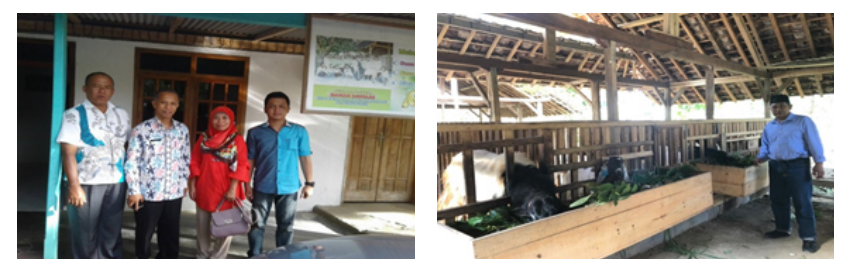

Gambar 4. Monitoring dan Evaluasi LPPM Uniska ke lokasi peternakan kambing milik mitra II.
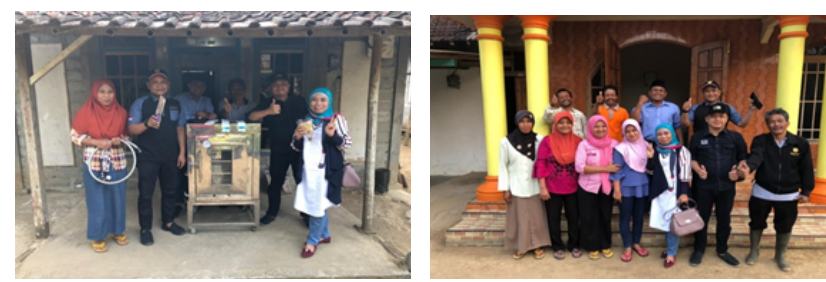

Gambar 5. Monitoring dan Evaluasi LPPM Uniska di Mitra I dan Mitra II

\section{Bantuan Alat Pengering Kerupuk Susu (Oven) dan Penggiling Susu Bubuk serta Pelatihan Cara Pengoperasian dan Maintanance.}

a. Pengering Kerupuk Susu (Oven)

Sebelum dilakukan penggorengan, selalu dilakukan pengeringan bahan kerupuk. Proses pengeringan menjadi tahapan yang sangat mempengaruhi kualitas hasil gorengan dari kerupuk. Kerupuk akan sulit mekar bila kurang kering. Krupuk dengan kondisi seperti ini sangat dihindari oleh pembuat kerupuk. Kerupuk menjadi keras sekali dan volomenya per satuan kerupuk menjadi kecil, keadaan seperti ini sangat merugikan pengusaha kerupuk karena kondisi kerupuk seperti ini juga sangat dihindari oleh calon pembeli.

Proses pengeringan kerupuk sebelum digoreng selama ini dilakukan dengan cara dijemur pada panas matahari atau dianginanginkan di tempat terbuka begitu saja. Model pengeringan seperti ini sangat dipengaruhi oleh keadaan alam dalam hal ini cuaca. Ketika musim kemarau atau kebetulan hari tidak hujan dan cuaca cerah, maka proses pengeringan dapat dilakukan dengan relatif baik. Tetapi bila keadaan sebaliknya, yaitu ketika hari tidak cerah atau pada musim penghujan, proses pengeringan menjadi tidak bisa dilakukan dengan baik sehingga setelah digoreng hasilnya sangat tidak diharapkan dan sangat merugikan pengusaha kerupuk.
Proses pengeringan kerupuk yang sangat tergantung dari keadaan alam sebagaimana yang dijelaskan di atas dan dengan segala permasalahan yang muncul perlu dihindari dan dicari jalan keluarnya. Keberadaan mesin pengering kerupuk sebelum digoreng menjadi sangat mendesak diperlukan. Karena dengan menggunakan mesin proses pengeringan kerupuk menjadi tidak bergantung pada cuaca. Setiap saat dapat dilakukan proses pengeringan. Mesin pengering kerupuk yang digunakan harus bisa efektif dan efisien serta kualitas hasilnya pun tidak kalah dari kerupuk yang dikeringkan dengan menggunakan sinar matahari.

Spesifikasi alat pengering kerupuk yang diserahkan kepada mitra I dan mitra II adalah sebagai berikut:
Kapasitas
: $4 \mathrm{Rak} / 50 \mathrm{Kg}$
Dimensi Total
: $64 \times 60 \times 70 \mathrm{~cm}$
Ruang oven
: $40 \times 50 \times 60 \mathrm{~cm}$
Bahan Bagian dalam : Stainless Steel
Bagian Luar
: Stainless Steel
$\mathrm{Ra}$
: Stainless Steel
Frame
: Besi Kotak
Sumber panas
: Kompor LPG

Blower

Kontrol suhu

:s.d. 150 derajat (Otomatis)
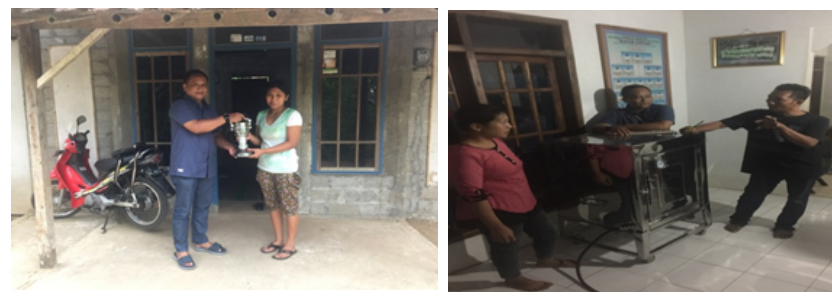

Gambar 6. Penyerahan Bantuan Alat Oven dan Penggiling Susu Bubuk kepada Mitra I dan Mitra II

b. Alat Penggiling Susu Bubuk

Selain pemberian bantuan alat berupa mesin pengering kerupuk, maka kepada mitra juga diberikan bantuan alat berupa penggling susu bubuk, dengan pertimbangan untuk pengembangan produk lain selain kerupuk susu di masa mendatang. 


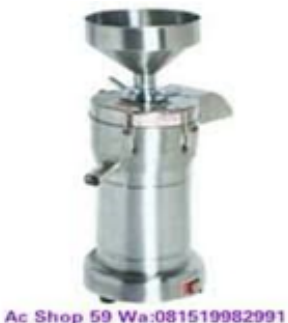

Gambar 7. Alat penggiling susu bubuk

Spesifikasi Alat :

$\begin{array}{ll}\text { Diameter Of Miling Plate } & : 100 \mathrm{~mm} \\ \text { Efficiency } & : 35 \mathrm{Kg} / \mathrm{H} \\ \text { Inpout Power } & : 0.75 \mathrm{~kW} \\ \text { Motor speed } & : 2800 \mathrm{Rmp} \\ \text { Voltage } & : 220 \mathrm{~V} \\ \text { Frequency } & : 50 \mathrm{~Hz} \\ \text { Dimension } & : 40 \times 25 \times 70 \mathrm{Cm}\end{array}$

\section{Proses Pengolahan Kerupuk Susu}

Seperti yang kita ketahiu bahwa kerupuk susu berbahan dasar susu segar, sehingga dapat disimpulkan bahwa kandungan gizi dari kerupuk susu sangat tinggi.

Peralatan yang diperlukan secara umum adalah alat-alat masak, yaitu:

- Baskom

- Kompor

- Panci

- Mangkok

- Blender

- Pisau

Bahan-bahan:

1. Susu kambing $500 \mathrm{ml}$

2. Tepung tapioka $300 \mathrm{gr}$

3. Tepung terigu $200 \mathrm{gr}$

4. Bawang putih secukupnya

5. Merica secukupnya

6. Penyedap rasa secukupnya

7. Baking powder $1 \%$ dari bobot total tepung (setara dengan 5 gram)

8. Garam secukupnya

9. Telur 1 butir

10. Cuka secukupnya

11. Air secukupnya
Susu yang akan digunakan dalam pembuatan kerupuk susu ini adalah dengan mengikuti pendapat Setiawati (2002) bahwa perbandingan susu dan tepung terigu 2,5 liter : $1 \mathrm{~kg}$ terigu, jadi perhitungannya menggunakan acuan pada berat tepung terigu yaitu jika terigu yang digunakan 200 gram maka susu yang akan dibutuhkan adalah $500 \mathrm{ml}$.

\section{Prosedur pembuatan kerupuk susu}

1. Memanaskan susu kambing dengan menambahkan cuka secukupnya sampai terjadi penggumpalan.

2. Menyaring gumpalan susu (curd) dengan saringan.

3. Menyampurkan curd dengan tepung tapioka dan tepung terigu ke dalam wadah.

4. Menambahkan bumbu-bumbu, telur, dan baking pawder ke dalam adonan.

5. Mengaduk adonan sampai kalis dengan menambahkan air matang secukupnya.

6. Menyiapkan wadah untuk mengukus.

7. Mencetak adonan dalam plastik dengan bentuk bulat memanjang/lonjong.

8. Mengukus adonan yang sudah dicetak tersebut sampai matang kira-kira \pm 1 jam kemudian diangkat.

9. Mendiamkan adonan sebentar sampai uapnya hilang.

10. Mengurangi kadar air adonan lonjong tersebut dengan memasukkannya dalam oven sampai setengah kering agar mudah untuk dipotong.

11.Memotong-potong adonan lonjong tadi tipistipis setebal $\pm 2 \mathrm{~mm}$.

12.Menjemur di bawah sinar matahari 1- 3 hari dengan temperatur rata-rata $30,4^{\circ} \mathrm{C}$ atau mengeringkan irisan kerupuk dalam oven sampai kering.

13. Setelah kering, kerupuk bisa digoreng dengan menggunakan minyak panas. menggunakan dengan suhu $180^{\circ} \mathrm{C}$ selama \pm 40 detik. 


\section{Bagan Proses Pembuatan Kerupuk Susu}

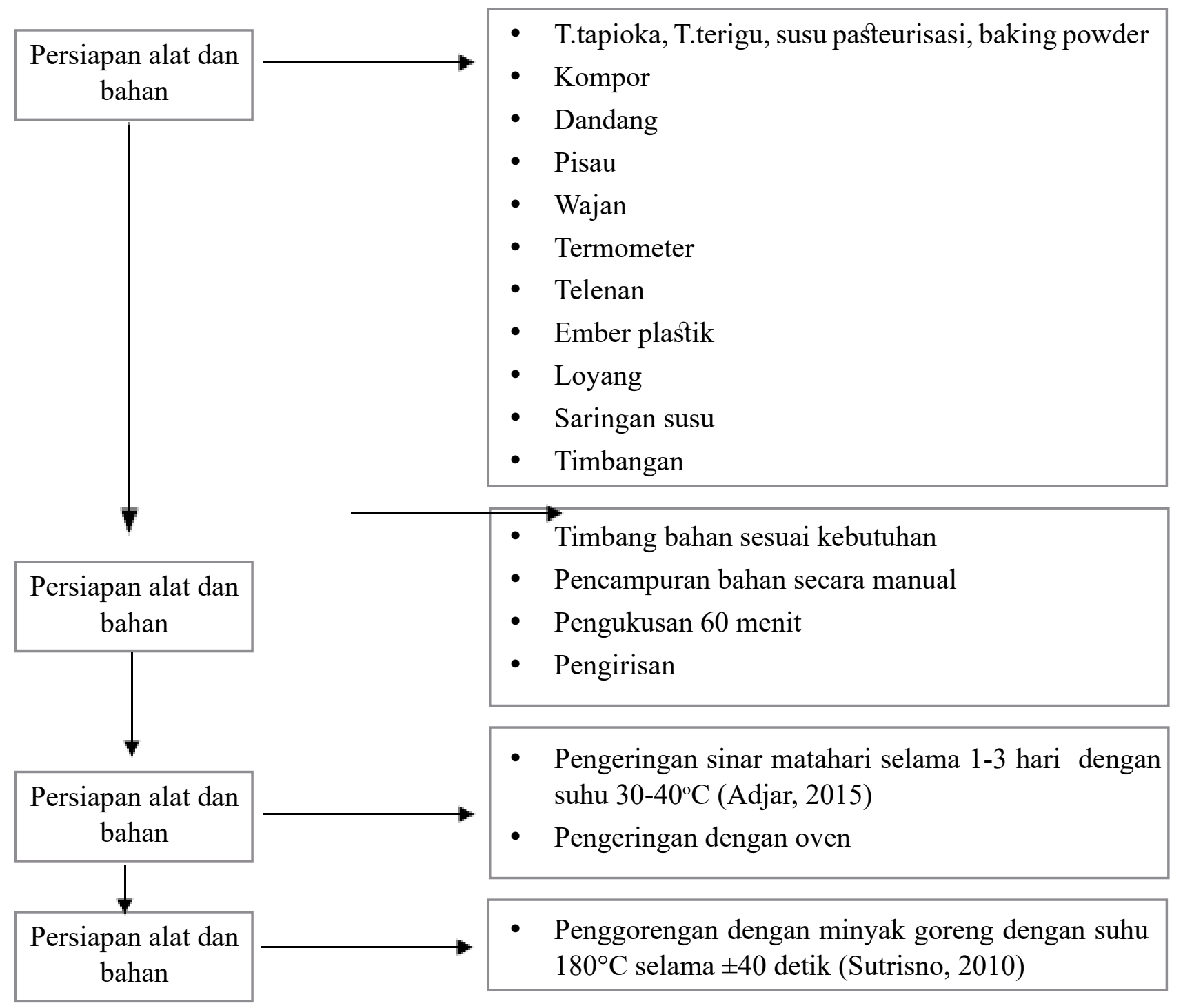

Gambar 8. Skema Pembuatan Kerupuk Susu Kambing
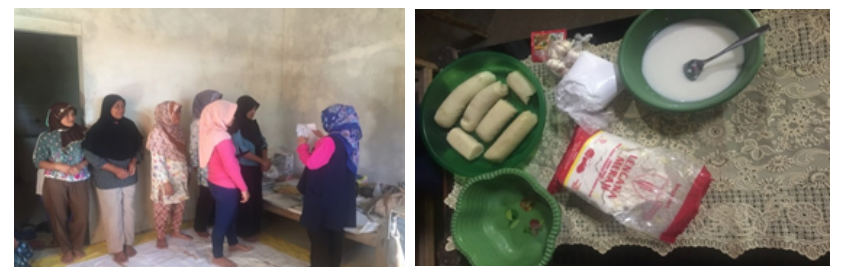

Gambar 9. Sosialisasi dan Pelatihan Pembuatan Kerupuk Susu
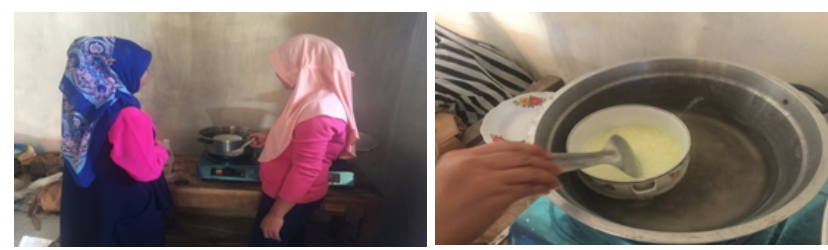

Gambar 10. Perebusan susu kambing dengan menambahkan cuka sampai terjadi penggumpalan.
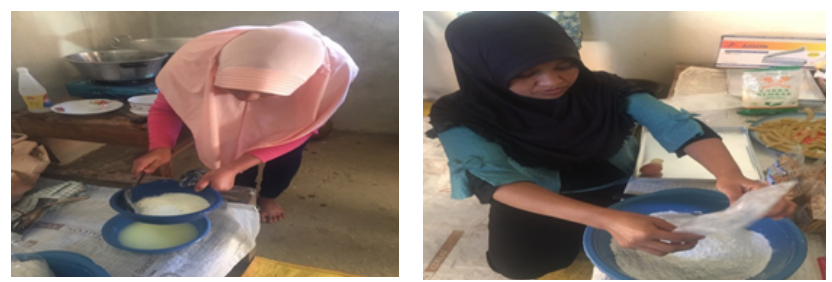

Gambar 11. Penyaringan susu yang sudah menggumpal (diambil gumpalannya : curd susu) dan pencampuran dengan tepung tapioka+terigu
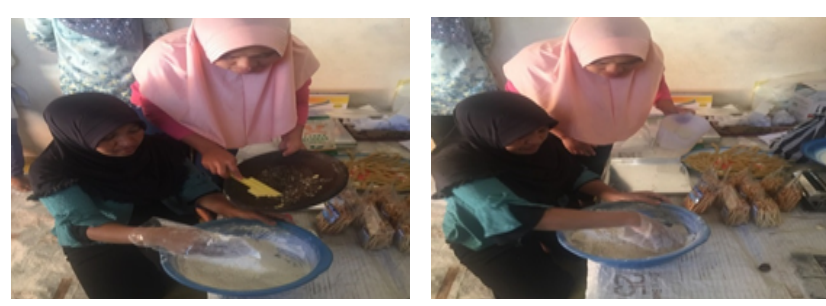

Gambar 12. Pencampuran adonan secara merata dan penambahan bumbu-bumbu dan baking powder 

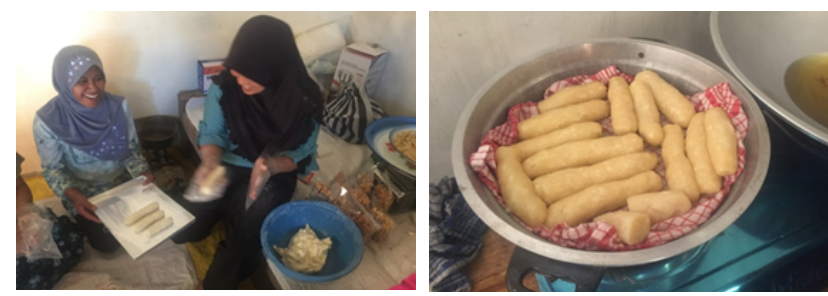

Gambar 13. Pembetukan adonan berbentuk bulat memanjang
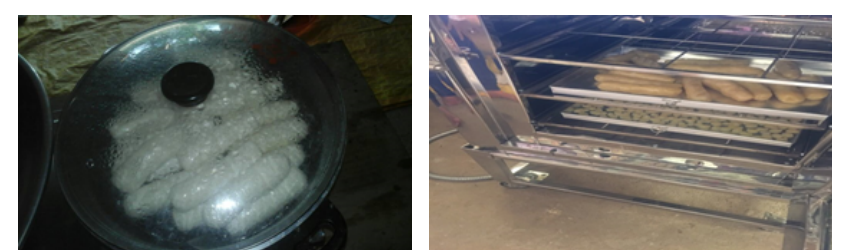

Gambar 14. Pengukusan adonan kerupuk susu yang sudah dibentuk (tanpa diberi kain lap) dan pengeringan kerupuk susu

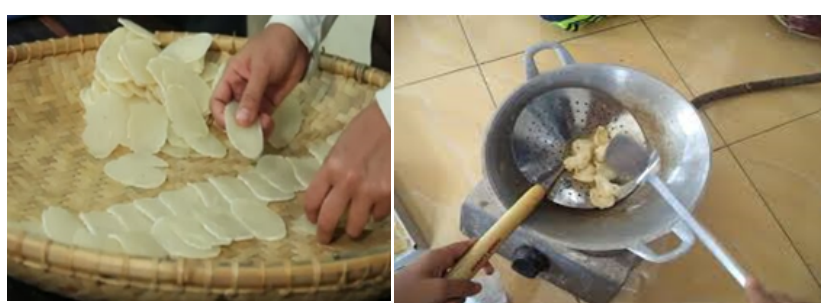

Gambar 15. Irisan kerupuk siap untuk dijemur. Setelah kering selanjutnya digoreng

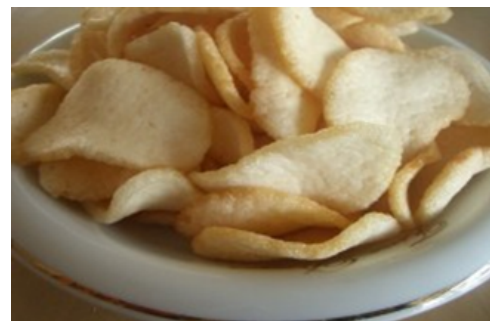

Gambar 16. Kerupuk Susu setelah digoreng

\section{Pengemasan Kerupuk Susu}

Fungsi pengemasan selain untuk menjaga kualitas kerupuk juga berperan untuk memperbaiki tampilan sehingga lebih menarik, mudah untuk mendistribusikan dan mudah dalam penyimpanannya. Pilihan kemasan yang tepat dapat melindungi kerupuk dari benturan agar tidak mudah hancur. Pengemasan produk menjadi lebih menarik dan informatif jika pada kemasan diberikan label, antara lain: Nama Produk, Gambar Produk, Komposisi bahan, Identitas produsen, Tanggal produk, Nama dan alamat produsen, Tanggal kadaluarsa, Nomor sertifikat produksi dan kode produksi, Berat bersih, dan Nomor izin dari badan POM/PIRT.
Paper bag atau dalam bahasa Indonesia disebut Tas Kertas kini menjadi salah satu media packaging untuk pengepack produk jualan, atau juga digunakan sebagai media/wadah souvenir dalam acara keluarga, perusahaan, dan juga acara resmi dari kementrian. Tas kertas, diklaim sebagai media packaging yang ramah lingkungan, karena sifat dari bahan yang digunakan mudah untuk didaur ulang. Pembuatan paper bag di dalam negeri, khususnya UMKM menggunakan bahan kertas yang jenisnya kurang lebihnya sama, yang membedakan biasanya dari PT/produsen/Suplier kertas, gramasi/ketebalan kertas, dan yang terakhir adalah model finishing paper bag.

Jenis kertas yang digunakan bisa di kelompokan menjadi tiga jenis; kertas kraft/ samson, kertas art paper/art carton, dan kertas marga/duplex.

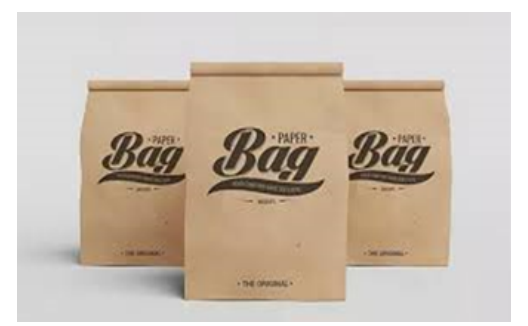

Gambar 17. Contoh Design Pengemas Kerupuk Susu

Spesifikasi Pengemas Kerupuk Susu:

- produk: paperbag samson kraft

- ukuran: Tinggi 22 x Lebar 16 x samping 8 $\mathrm{cm}$

- bahan: samson kraft 90 gsm

- warna: 1 warna

\section{Pemasaran Kerupuk Susu secara online}

Produk krupuk susu yang dihasilkan mitra I dan mitra II masih dipasarkan secara tradisional yaitu berdasarkan pesanan dan dititipkan di warung-warung sekitar rumah. Sehingga dapat dikatakan volume penjualan produk krupuk susu masih sedikit. Dalam rangka memperluas pemasarannya maka TIM Pengmas Uniska memberikan solusi dengan memanfaatkan kemajuan teknologi informasi yaitu dengan pemasaran produk secara online. Alamat web yang dapat diakses oleh konsumen adalah www. 
banarlestari.usahaku.id dan www.kertausaha. usahaku.id

Keunggulan web tersebut adalah:

1 .Termasuk kategori web e-commerce

2. Memiliki dukungan untuk sistem penjualan online lainnya (antara lain promo; diskon; berita)

3. Fasilitas Google map

4 .Panel admin yang dinamis sehinga dapat diubah sesuai keinginan

\section{KESIMPULAN DAN SARAN}

\section{Kesimpulan}

Kesimpulan dari pelaksanaan program PKM ini adalah kedua mitra sudah mulai memahami dan memiliki ketrampilan dalam hal :

1. Cara mengidentifikasi susu yang berkualitas bagus maupun yang berkualitas rendah, serta dapat mengolahnya menjadi kerupuk susu.

2. Cara melakukan uji fisik dan uji organoleptik kerupuk susu yang dihasilkan.

3. Pengoperasian dan perawatan mesin pengering dan pengiris/pemotong kerupuk.

4. Cara mengidentifikasi bahan-bahan pengemas yang aman untuk makanan dan mampu melakukan pengemasan produk kerupuk susu yang dihasilkan.

5. Pemasaran produk telur asin secara on line

6. Pengurusan PIRT produk dan aktif dalam kegiatan pembinaan dari Dinas Kesehatan

7. Pencatatan keuangan usaha secara tertib.

\section{Saran}

Agar susu kambing yang dihasilkan oleh kelompok ternak di Kecamatan Suruh Kabupaten Trenggalek dapat terus dikembangkan produksi dan pengolahan produknya, maka kiranya sangat diperlukan program kerja dan dukungan dana yang sinergis antara UNISKA dengan instansi terkait baik pemerintah maupun swasta.

\section{REFERENSI}

Buckle, K, A., R, A Edwards, G, H., Flett, M., Wootton. 1997. Ilmu Pangan. Universitas
Indonesia. Jakarta. dikutip dari Yustina Ita. 2012. Pengaruh Penambahan Aneka Rempah Terhadap Sifat Fisik, Organoleptik serta Kesukaan Pada Kerupuk dari Susu Sapi Segar. Fakultas Pertanian Universitas Trunojoyo Madura. Madura.

Djumali, Z., I. Nasution, Sailah dan M. S. Ma'arif. 2003. Teknologi Kerupuk. IPB. Bogor.

Firman, Achmad. 2010. Agribisnis Sapi Perah Dari Hulu Sampai Hilir. Widya Padjajaran. Bandung.

Ita, Yustina., Ericha Nurvia A., Aniswatul. 2012. Pengaruh Penambahan Aneka Rempah Terhadap Sifat Fisik Organoleptik serta Kesukaan Pada Kerupuk dan Susu sapi Segar. Kedaulatan Pangan dan Energi Fakultas Pertanian Universitas Trunojoyo Madura. BPTP Jawa Timur. Malang.

Ratna, E., 2016. Karakteristik Organoleptik Kerupuk Susu dengan Taraf Pemberian Baking Powder yang Berbeda. Jurnal Ilmiah Fillia Cendekia. Vol 2 Nomor 1.

Rihastuti. 1993. Kualitas Kerupuk Susu Yang Dibuat Dengan Perbedaan Jenis Tepung. Buletin Peternakan, vol. 17, Fakultas Peternakan UGM. Yogyakarta.

Rose. 1992. Pengaruh Konsentrasi Tepung Tapioka dan Terigu Terhadap Mutu Kerupuk Susu. Skripsi. Fakultas Teknologi Jurusan Teknologi Pangan dan Gizi. Universitas Katolik Widya Mandala. Surabaya.

Wahyudi. 1991. Penggunaan Curd dan Baking Powder Pada Pembuatan Kerupuk Susu. Penelitian Balai Besar Pelatihan Peternakan. BBPP, Batu.

Wiriono, H. 1984. Mekanisme Teknologi Pembuatan Kerupuk. Balai Pengembangan Makanan Phytokimia, Badan Penelitian dan Pengembangan Industri, Departemen Perindustrian. Jakarta. 